\title{
Brachymonas chironomi sp. nov., isolated from a chironomid egg mass, and emended description of the genus Brachymonas
}

Correspondence

Malka Halpern

mhalpern@research.haifa.ac.il

\author{
Malka Halpern, ${ }^{1}$ Tamar Shakèd ${ }^{1}$ and Peter Schumann ${ }^{2}$ \\ ${ }^{1}$ Department of Biology, Faculty of Science and Science Education, University of Haifa, Oranim, \\ Tivon 36006, Israel \\ ${ }^{2}$ DSMZ-Deutsche Sammlung von Mikroorganismen und Zellkulturen GmbH, Inhoffenstraße 7B, \\ D-38124 Braunschweig, Germany
}

\begin{abstract}
A Gram-negative, aerobic, chemo-organotrophic, catalase- and oxidase-positive strain, designated AIMA4 ${ }^{\top}$, was isolated from a chironomid (Diptera; Chironomidae) egg mass which was sampled from a waste stabilization pond in northern Israel. Phylogenetic analysis based on the $16 \mathrm{~S}$ rRNA gene placed strain AIMA4 ${ }^{\top}$ in the genus Brachymonas (class Betaproteobacteria). Strain AIMA4 ${ }^{\top}$ shared $16 \mathrm{~S}$ rRNA gene sequence similarity values of $96.9 \%$ with Brachymonas denitrificans $\mathrm{JCM} 9216^{\top}$ and $<95.7 \%$ with the type strains of other genera. Strain AIMA4 ${ }^{\top}$ was found to be a non-motile coccobacillus or rod that did not grow under anaerobic conditions and did not produce acid from carbohydrates. Growth was observed at salinities from 0 to $2.5 \%(\mathrm{w} / \mathrm{v})$ $\mathrm{NaCl}$, at $\mathrm{pH}$ values from 5.0 to 9.0 and at temperatures from 18 to $37{ }^{\circ} \mathrm{C}$. The major fatty acids $(>10 \%)$ of strain AIMA4 ${ }^{\top}$ were $\mathrm{C}_{16: 1} \omega 7 c, \mathrm{C}_{16: 0}$ and $\mathrm{C}_{18: 1} \omega 7 c$. Phosphatidylethanolamine, phosphatidylglycerol and phosphatidylserine were the predominant components of the polar lipids. The major ubiquinone was Q-8. On the basis of phenotypic properties and phylogenetic

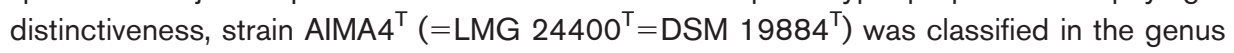
Brachymonas as the type strain of a novel species for which the name Brachymonas chironomi sp. nov. is proposed.
\end{abstract}

The genus Brachymonas was created by Hiraishi et al. (1995a) while characterizing rhodoquinone-containing bacteria that had been isolated from soybean crude waste sludge. At present, the genus comprises only one species: Brachymonas denitrificans (Hiraishi et al., 1995a, b). In this study, a new member of the genus Brachymonas (family Comamonadaceae, class Betaproteobacteria) that was isolated from a freshwater insect egg mass is proposed on the basis of a taxonomic study using a polyphasic approach.

Chironomids (Diptera; Chironomidae) are the most abundant insects in freshwater aquatic habitats. Females of the genus Chironomus lay egg masses at the water's edge. Each egg mass contains hundreds of eggs embedded in a thick, gelatinous matrix. Chironomid egg masses harbour Vibrio cholerae and provide a natural reservoir for this bacterium (Broza \& Halpern, 2001; Halpern et al., 2004).

\footnotetext{
The GenBank/EMBL/DDBJ accession number for the 16S rRNA gene sequence of strain AIMA4 ${ }^{\top}$ is EU346912.

An electron micrograph of negatively stained cells of strain AIMA $^{\top}$, polar lipid profiles of Brachymonas denitrificans DSM $15123^{\top}$ and strain AIMA $4^{\top}$, and a table detailing the fatty acid contents of Brachymonas denitrificans DSM $15123^{\top}$ and strain AIMA4 ${ }^{\top}$ are available as supplementary material with the online version of this paper.
}

All isolates of $V$. cholerae have the ability to degrade chironomid egg masses and prevent the eggs from hatching (Halpern et al., 2003, 2006). Strain AIMA4 ${ }^{\mathrm{T}}$, an aerobic, non-motile Gram-negative short rod, was isolated during a study into the diversity of the culturable bacteria present in chironomid egg masses. Strain $\mathrm{AIMA} 4^{\mathrm{T}}$ did not possess the ability to degrade chironomid egg masses.

Chironomid egg masses were sampled as previously described (Halpern et al., 2007). To determine the diversity of culturable bacteria, the egg masses were thoroughly washed with sterile saline water. Homogenates from the masses were then diluted and cultured directly on m-Aeromonas medium (Himedia), a selective agar that enhances the growth of members of the genus Aeromonas. Strain AIMA4 ${ }^{\mathrm{T}}$ was isolated in July 2006 from an egg mass that was sampled from a waste stabilization pond in northern Israel, cultured on m-Aeromonas agar and incubated at $30{ }^{\circ} \mathrm{C}$ for $48 \mathrm{~h}$ in the dark. The $16 \mathrm{~S}$ rRNA gene sequence of strain AIMA4 $4^{\mathrm{T}}$ was analysed to determine its phylogenetic position. The universal bacterial primers $8 \mathrm{f}$ and 1512r (Felske et al., 1997) were used to amplify internal fragments of the 16S rRNA gene. Purified PCR products were sequenced with $8 \mathrm{f}, 534 \mathrm{r}, 968 \mathrm{f}$ and $1512 \mathrm{r}$ primers as described in detail by Raats \& Halpern (2007). 
This resulted in a sequence of approximately $1500 \mathrm{bp}$. The identification of phylogenetic neighbours was initially carried out by the BLAST (Altschul et al., 1997) and FASTA (Pearson \& Lipman, 1988) programs against the database of type strains with validly published prokaryotic names (Chun et al., 2007). The 50 sequences with the highest scores were then selected for the calculation of pairwise sequence similarity using a global alignment algorithm, which was implemented using the EzTaxon server (http:// www.eztaxon.org/; Chun et al., 2007). Sequence alignment was performed using the CLUSTAL $\mathrm{W}$ program and a phylogenetic tree (Fig. 1) was generated using the neighbour-joining method with MEGA version 4 software (Tamura et al., 2007). The $1500 \mathrm{bp}$ sequence of strain $\mathrm{AIMA}^{\mathrm{T}}$ shared highest sequence similarity of $96.9 \%$ with that of B. denitrificans JCM $9216^{\mathrm{T}}$ and $<95.7 \%$ with the type strains of other genera (Fig. 1).

For electron microscopy, bacteria in Luria-Bertani (LB) agar medium were suspended in saline. The samples were fixed to a carbon-coated grid and stained with $2 \%$ uranyl acetate and photographed under a JEM-1200EX electron microscope (JEOL). Electron microscopy showed that the cells were coccobacilli or rods measuring $0.75-1.2 \mu \mathrm{m}$ in width and 1.0-3.0 $\mu \mathrm{m}$ in length (see Supplementary Fig. S1 in IJSEM Online).

For phenotypic characterization, LB agar was used as the basal growth medium. Salt tolerance was determined at $30{ }^{\circ} \mathrm{C}$ on LB agar containing $0-5 \%(\mathrm{w} / \mathrm{v}) \mathrm{NaCl}$. Growth at $10,14,18,25,30,33,37,40$ and $45{ }^{\circ} \mathrm{C}$ was measured using $\mathrm{LB}$ agar. The $\mathrm{pH}$ range for growth was determined using LB broth adjusted to $\mathrm{pH} 4.0-8.0$ at 1.0 unit intervals. The $\mathrm{pH}$ was adjusted prior to sterilization by the addition of $\mathrm{HCl}$ or $\mathrm{NaOH}$ and measured again after sterilization. For alkaline medium, LB broth was adjusted to $\mathrm{pH} 9.0,9.5$ and 10.0 with $0.1 \mathrm{M} \mathrm{Na}_{2} \mathrm{CO}_{3}$ or $0.1 \mathrm{M}$ $\mathrm{NaHCO}_{3}$ and then filtered through a $0.2 \mu \mathrm{m}$ pore size filter (Corning) to obtain a sterilized medium. Growth under anaerobic conditions was determined after incubation in an anaerobic chamber on LB agar supplemented with $0.5 \%(\mathrm{w} / \mathrm{v})$ glucose or $0.1 \%(\mathrm{w} / \mathrm{v})$ potassium nitrate. Biochemical tests were performed by using API 20E, API 20NE, API 50CH and API ZYM identification systems (bioMérieux), according to the manufacturer's instructions, except that the incubation temperature was $30{ }^{\circ} \mathrm{C}$. Catalase activity was evidenced by bubble production in a $3 \%(\mathrm{v} / \mathrm{v})$ hydrogen peroxide solution. Oxidase activity was determined using $1 \% \quad N, N, N^{\prime}, N^{\prime}$-tetramethylp-phenylenediamine dihydrochloride (Sigma-Aldrich, T3134). Growth was tested on MacConkey agar (Difco) and cetrimide agar (Himedia). The phenotypic traits of the novel isolate are given in the species description and in Table 1.

For cellular fatty acid analysis, strain $\mathrm{AIMA}^{\mathrm{T}}$ and $B$. denitrificans DSM $15123^{\mathrm{T}}$ were cultured on tryptic soy agar (Difco) for $24 \mathrm{~h}$ at $28{ }^{\circ} \mathrm{C}$. Fatty acids were then extracted, methylated and analysed by GC using the Sherlock Microbial Identification system (MIDI) as described by Kämpfer \& Kroppenstedt (1996). The identity of the major components was confirmed by GC/MS by using a Singlequad 320 instrument (Varian). Strain $\mathrm{AIMA}^{\mathrm{T}}{ }^{\mathrm{T}}$ and B. denitrificans DSM $15123^{\mathrm{T}}$ had a similar fatty acid profile with respect to the occurrence of $\mathrm{C}_{16: 1} \omega 7 c, \mathrm{C}_{16: 0}$ and $\mathrm{C}_{18: 1} \omega 7 \mathrm{c}$ as the major fatty acids. Strain AIMA4 ${ }^{\mathrm{T}}$ had a higher content of $\mathrm{C}_{14: 0}$ and a lower content of $\mathrm{C}_{12: 0}$ (see Supplementary Table S1 in IJSEM Online).

For polar lipid and isoprenoid quinone analyses, strains AIMA4 $4^{\mathrm{T}}$ and B. denitrificans DSM $15123^{\mathrm{T}}$ were cultivated on complex PBY medium (Hiraishi \& Komagata, 1989) at $28{ }^{\circ} \mathrm{C}$ for $24 \mathrm{~h}$ (strain DSM $15123^{\mathrm{T}}$ ) or $48 \mathrm{~h}$ (strain AIMA4 ${ }^{\mathrm{T}}$ ) until the necessary amount of biomass was obtained. The polar lipids of strains $\mathrm{AIMA}^{\mathrm{T}}$ and $B$. denitrificans DSM $15123^{\mathrm{T}}$ were extracted according to

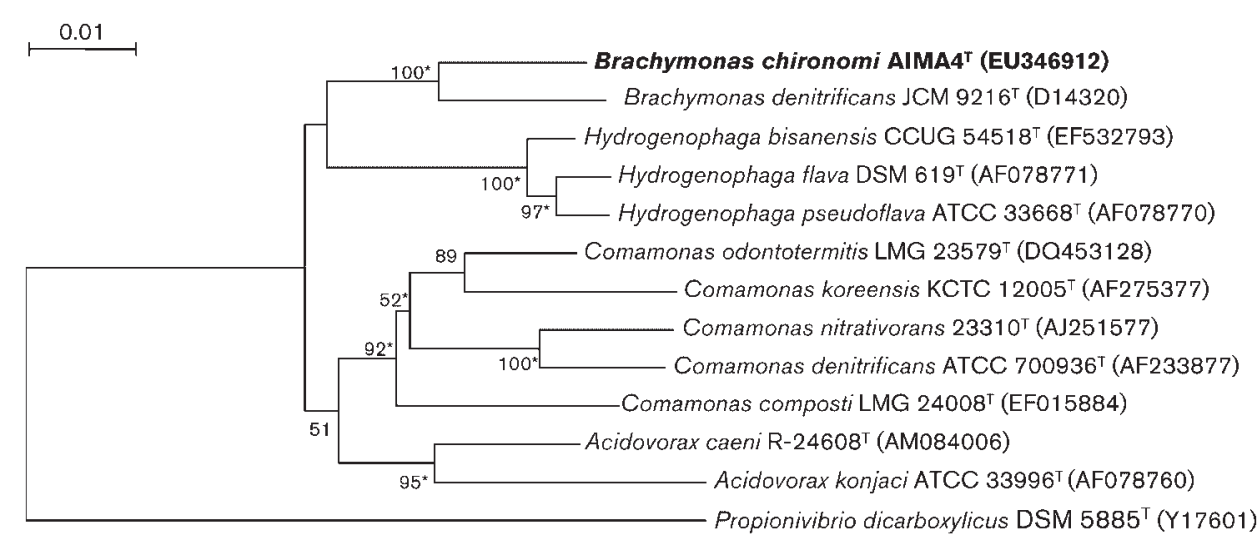

Fig. 1. Neighbour-joining dendrogram of $16 \mathrm{~S}$ rRNA gene sequences obtained from Brachymonas chironomi sp. nov. AIMA4 ${ }^{\top}$ and related species and genera. Bootstrap values (>50\%) resulting from 1000 replicates are indicated at branching nodes. Propionivibrio dicarboxylicus was used as an outgroup. Asterisks indicate the branches of the tree that were also formed by using the maximum-parsimony method. Bar, 0.01 substitutions per nucleotide position. 
Table 1. Characteristics that differentiate strain AIMA4 ${ }^{\top}$ and $B$. denitrificans DSM $15123^{\top}$

Strains: 1 , AIMA4 $4^{\mathrm{T}} ; 2$, B. denitrificans DSM $15123^{\mathrm{T}}$. +, Positive; -, negative; w, weak.

\begin{tabular}{|c|c|c|}
\hline Characteristic & 1 & 2 \\
\hline Cell size $(\mu \mathrm{m})$ & $0.75-1.2 \times 1.0-3.0$ & $0.6-1.0 \times 1.2-2.0$ \\
\hline DNA G $+C$ content $(\mathrm{mol} \%)$ & 60 & $63-65$ \\
\hline Pigment & $\begin{array}{l}\text { Beige that turns to light brown } \\
\text { (after few days of incubation) }\end{array}$ & Cream or pale yellow \\
\hline Quinones & Q-8, Q-7, Q-9 & Q-8 \\
\hline Rhodoquinones & None & RQ-8 \\
\hline Anaerobic growth & - & + \\
\hline $\mathrm{NaCl}$ range for growth $(\%, w / v)$ & $0-2.5$ & $0-3$ \\
\hline \multicolumn{3}{|l|}{ Growth temperature $\left({ }^{\circ} \mathrm{C}\right)$} \\
\hline Range & $18-37$ & $10-40$ \\
\hline Optimum & 30 & $30-35$ \\
\hline MacConkey agar & w (after $96 \mathrm{~h}$ ) & - \\
\hline Tryptophan deaminase & - & + \\
\hline Acetoin production & + & - \\
\hline Nitrate reduction to nitrite & + & - \\
\hline Nitrate reduction to $\mathrm{N}_{2}$ & - & + \\
\hline \multicolumn{3}{|l|}{ Assimilation of: } \\
\hline$N$-Acetyl-glucosamine & - & + \\
\hline Adipate & - & + \\
\hline Arabinose & - & + \\
\hline Citrate & - & + \\
\hline Gluconate & - & + \\
\hline Glucose & - & + \\
\hline Malate & - & + \\
\hline Maltose & - & + \\
\hline Mannitol & - & + \\
\hline Mannose & - & + \\
\hline
\end{tabular}

Minnikin et al. (1979) and analysed by two-dimensional TLC (Collins \& Jones, 1980). Strains AIMA4 ${ }^{\mathrm{T}}$ and $B$. denitrificans DSM $15123^{\mathrm{T}}$ contained phosphatidylglycerol, phosphatidylethanolamine and phosphatidylserine. $B$. denitrificans DSM $15123^{\mathrm{T}}$ also contained diphosphatidylglycerol, two unknown phospholipids and an unknown aminophospholipid (see Supplementary Fig. S2 in IJSEM Online). Isoprenoid quinone analysis of strain AIMA4 ${ }^{\mathrm{T}}$ was performed by HPLC as described by Groth et al. (1996). Strain AIMA4 ${ }^{\mathrm{T}}$ contained the ubiquinones Q-8, Q-7 and Q-9 in an approximate molar ratio of 96:2:1 (Table 1). In addition to the major component ubiquinone Q-8, B. denitrificans DSM $15123^{\mathrm{T}}$ also contained rhodoquinone RQ-8. Rhodoquinone RQ-8 gave rise to a purple band migrating around $75 \%$ slower than the yellow band of Q-8 on silica gel TLC plates when benzene was used as the developing solvent (Hiraishi \& Hoshino, 1984). The mass spectrum of RQ-8 recorded after elution from the TLC plate by using a Singlequad 320 MS equipped with a direct insertion probe device (Varian) showed the molecular ion at $m / z 711$ and fragment ions at $m / z 235$ and 220. Since additional peaks at $m / z$ 698, 205 and 167 (instead of the fragment ion at $m / z \quad 182$ as reported by Hiraishi \& Hoshino, 1984) were recorded, it appears likely that demethylated RQ-8 was also present. The quinone extract of strain AIMA4 ${ }^{\mathrm{T}}$ did not contain any detectable traces of rhodoquinones.

DNA was isolated after disruption of cells by using a French pressure cell and purified by hydroxyapatite chromatography (Cashion et al., 1977). DNA was degraded to nucleosides by P1 nuclease and bovine intestinal mucosa alkaline phosphatase (Roche Diagnostics) as described by Mesbah et al. (1989). The nucleosides were separated by reversed-phase HPLC by using the method described by Tamaoka \& Komagata (1984). Lambda phage DNA and three bacterial DNAs (Bacillus subtilis DSM 402, Xanthomonas campestris pv. campestris DSM $3586^{\mathrm{T}}$ and Streptomyces violaceoruber DSM 40783) with published genome sequences were used as standards. The $\mathrm{G}+\mathrm{C}$ content of the DNA of strain AIMA4 ${ }^{\mathrm{T}}(60 \mathrm{~mol} \%)$ was calculated from the ratio of deoxyguanosine to thymidine.

The novel isolate, being aerobic, chemo-organotrophic, non-motile, coccobacilli or rods, catalase- and oxidasepositive, giving no acid production from sugars including glucose, containing $\mathrm{C}_{16: 0}$ as the dominant fatty acid, showing an absence of lysine and ornithine decarboxylases, being negative for indole production and for urea and gelatin hydrolysis, shared the main characteristics of $B$. denitrificans. However, it differed from $B$. denitrificans by 
means of several phenotypic traits, as listed in Table 1, and especially by its inability to grow under anaerobic conditions, its ability to reduce nitrate only to nitrite (and not to nitrogen) and by the absence of rhodoquinones.

On the basis of the phenotypic characterization and a $16 \mathrm{~S}$ rRNA gene sequence similarity of $<97 \%$ to its closest phylogenetic neighbour B. denitrificans (Stackebrandt \& Goebel, 1994), we propose that the description of the genus Brachymonas should be emended and strain AIMA4 $4^{\mathrm{T}}$ should be classified as the type strain of a novel species of the genus Brachymonas species, for which the name Brachymonas chironomi sp. nov. is proposed.

\section{Emended description of genus Brachymonas Hiraishi et al. 1995}

Brachymonas (Bra.chy.mo' nas. Gr. adj. brachy short; Gr. n. monas a unit, monad; M.L. fem. n. Brachymonas a small short unit).

The description is as given by Hiraishi et al. (1995a) with the following amendments. Nitrate is reduced to nitrite or nitrogen. Neutrophilic and non-halophilic. The major cellular fatty acids are $\mathrm{C}_{16: 1} \omega 7 c, \mathrm{C}_{16: 0}$ and $\mathrm{C}_{18: 1} \omega 7 c$ and phosphatidylglycerol, phosphatidylethanolamine and phosphatidylserine occur as polar lipids. The major quinone is ubiquinone Q-8. Rhodoquinone RQ-8 may occur in some species. The DNA $\mathrm{G}+\mathrm{C}$ values are in the range of 60 to $65 \mathrm{~mol} \%$. The type species is Brachymonas denitrificans.

\section{Description of Brachymonas chironomi sp. nov.}

Brachymonas chironomi [chi.ro' no.mi. N.L. gen. n. chironomi of Chironomus, named after the non-biting midge insect from the genus Chironomus (Chironomidae: Diptera) from which the type strain was isolated].

Cells are Gram-negative, catalase and oxidase-positive, non-motile coccobacilli or rods measuring $0.75-1.2 \mu \mathrm{m}$ in width and $1.0-3.0 \mu \mathrm{m}$ in length. Cells occur singly or in pairs, sometimes in chains. After $48 \mathrm{~h}$ incubation on LB agar at $30{ }^{\circ} \mathrm{C}$, beige coloured colonies are circular, smooth, convex and opaque with entire margins. After a few days incubation, the colony colour changes to brown-beige. Good growth occurs under aerobic conditions. Growth is not observed under anaerobic conditions even after 8 days incubation. Growth is observed after $48 \mathrm{~h}$ incubation at $18-37{ }^{\circ} \mathrm{C}$ (optimum $30{ }^{\circ} \mathrm{C}$ ), with $0-2.5 \%$ (w/v) $\mathrm{NaCl}$ (optimum $0.5 \% \mathrm{NaCl}$ ) and at $\mathrm{pH} 5.0-9.0$ (optimum $\mathrm{pH}$ 6.0-8.0). Growth is observed on Zobell marine (Himedia) and MacConkey (weak growth) agars, but not on cetrimide agar. Catalase and oxidase activities are present. The following results are obtained from API 20NE after $48 \mathrm{~h}$ of incubation at $30{ }^{\circ} \mathrm{C}$ : nitrate is reduced to nitrite; phenylacetic acid is assimilated. The following results are obtained from API $20 \mathrm{E}$ strips after $48 \mathrm{~h}$ of incubation at $30{ }^{\circ} \mathrm{C}$ : nitrate is reduced to nitrite; acetoin is produced; $\mathrm{H}_{2} \mathrm{~S}$ and indole are not produced; urea and gelatin are not hydrolysed; citrate is not utilized; and $\beta$ galactosidase, arginine dihydrolase, lysine- and ornithine decarboxylases and tryptophan deaminase activities are absent. In API $50 \mathrm{CH}$ strips incubated for $48 \mathrm{~h}$ at $30{ }^{\circ} \mathrm{C}$, acid is not produced from any of the carbohydrate substrates. In API ZYM strips incubated for $4.5 \mathrm{~h}$ at $30{ }^{\circ} \mathrm{C}$, weakly positive activities are observed for the following enzymes: alkaline and acid phosphatases, esterase (C4), esterase lipase (C8), leucine arylamidase, valine arylamidase, trypsin and naphthol-AS-BI-phosphohydrolase. The dominant cellular fatty acids of the type strain are $\mathrm{C}_{16: 1} \omega 7 c, \mathrm{C}_{16: 0}$ and $\mathrm{C}_{18: 1} \omega 7 c$. The main isoprenoid quinone is Q-8. Phosphatidylglycerol, phosphatidylethanolamine and phosphatidylserine occur as polar lipids.

The type strain, AIMA4 $^{\mathrm{T}}\left(=\mathrm{LMG} 24400^{\mathrm{T}}=\mathrm{DSM} 19884^{\mathrm{T}}\right)$, was isolated from a chironomid egg mass in Israel. The DNA G + C content of the type strain is $60 \mathrm{~mol} \%$ (HPLC).

\section{Acknowledgements}

The authors thank Mrs Gabriele Pötter and Mrs Anika Wasner (both DSMZ) for excellent technical assistance in chemotaxonomic analyses. Strain $\mathrm{AIMA}^{\mathrm{T}}$ was isolated by Inbal Hindin and Yifat Edri in the course of a microbial ecology workshop.

\section{References}

Altschul, S. F., Madden, T. L., Schäffer, A. A., Zhang, J., Zhang, Z., Miller, W. \& Lipman, D. J. (1997). Gapped BLAST and PSI-BLAST: a new generation of protein database search programs. Nucleic Acids Res 25, 3389-3402.

Broza, M. \& Halpern, M. (2001). Pathogen reservoirs: Chironomid egg masses and Vibrio cholerae. Nature 412, 40.

Cashion, P., Holder-Franklin, M. A., McCully, J. \& Franklin, M. (1977). A rapid method for base ratio determination of bacterial DNA. Anal Biochem 81, 461-466.

Chun, J., Lee, J.-H., Jung, Y., Kim, M., Kim, S., Kim, B. K. \& Lim, Y. W. (2007). EzTaxon: a web-based tool for the identification of prokaryotes based on $16 \mathrm{~S}$ ribosomal RNA gene sequences. Int J Syst Evol Microbiol 57, 2259-2261.

Collins, M. D. \& Jones, D. (1980). Lipids in the classification and identification of coryneform bacteria containing peptidoglycans based on 2,4-diaminobutyric acid. J Appl Bacteriol 48, 459-470.

Felske, A., Rheims, H., Wolterink, A., Stackebrandt, E. \& Akkermans, A. D. (1997). Ribosome analysis reveals prominent activity of an uncultured member of the class Actinobacteria in grassland soils. Microbiology 143, 2983-2989.

Groth, I., Schumann, P., Weiss, N., Martin, K. \& Rainey, F. A. (1996). Agrococcus jenensis gen. nov., sp. nov., a new genus of actinomycetes with diaminobutyric acid in the cell wall. Int J Syst Bacteriol 46, 234239.

Halpern, M., Gancz, H., Broza, M. \& Kashi, Y. (2003). Vibrio cholerae hemagglutinin/protease degrades chironomid egg masses. Appl Environ Microbiol 69, 4200-4204.

Halpern, M., Broza, Y. B., Mittler, S., Arakawa, E. \& Broza, M. (2004). Chironomid egg masses as a natural reservoir of Vibrio cholerae non$\mathrm{O} 1$ and non-O139 in freshwater habitats. Microb Ecol 47, 341-349. 
Halpern, M., Raats, D., Lavion, R. \& Mittler, S. (2006). Dependent population dynamics between Chironomids (non-biting midges) and Vibrio cholerae. FEMS Microbiol Ecol 55, 98-104.

Halpern, M., Landsberg, O., Raats, D. \& Rosenberg, E. (2007). Culturable and VBNC Vibrio cholerae; Interactions with chironomid egg masses and their bacterial population. Microb Ecol 53, 285-293.

Hiraishi, A. \& Hoshino, Y. (1984). Distribution of rhodoquinone in Rhodospirillaceae and its taxonomic implications. J Gen Appl Microbiol 30, 435-448.

Hiraishi, A. \& Komagata, K. (1989). Effects of the growth medium composition on menaquinone homolog formation in Micrococcus luteus. J Gen Appl Microbiol 35, 311-318.

Hiraishi, A., Shin, Y. K. \& Sugiyama, J. (1995a). Brachymonas denitrificans gen. nov., sp. nov., an aerobic chemoorganotrophic bacterium which contains rhodoquinones, and evolutionary relationships of rhodoquinone producers to bacterial species with various quinone classes. J Gen Appl Microbiol 41, 99-117.

Hiraishi, A., Shin, Y. K. \& Sugiyama, J. (1995b). Brachymonas denitrificans gen. nov., sp. nov. In Validation of the Publication of New Names and New Combinations Previously Effectively Published Outside the IJSB, List no. 55. Int J Syst Bacteriol 45, 879-880.
Kämpfer, P. \& Kroppenstedt, R. M. (1996). Numerical analysis of fatty acid patterns of coryneform bacteria and related taxa. Can J Microbiol 42, 989-1005.

Mesbah, M., Premachandran, U. \& Whitman, W. B. (1989). Precise measurement of the $\mathrm{G}+\mathrm{C}$ content of deoxyribonucleic acid by highperformance liquid chromatography. Int J Syst Bacteriol 39, 159-167.

Minnikin, D. E., Collins, M. D. \& Goodfellow, M. (1979). Fatty acid and polar lipid composition in the classification of Cellulomonas, Oerskovia and related taxa. J Appl Bacteriol 47, 87-95.

Pearson, W. R. \& Lipman, D. J. (1988). Improved tools for biological sequence comparison. Proc Natl Acad Sci U S A 85, 2444-2448.

Stackebrandt, E. \& Goebel, B. M. (1994). Taxonomic note: a place for DNA-DNA reassociation and 16S rRNA sequence analysis in the present species definition in bacteriology. Int J Syst Bacteriol 44, 846-849.

Tamaoka, J. \& Komagata, K. (1984). Determination of DNA base composition by reversed-phase high-performance liquid chromatography. FEMS Microbiol Lett 25, 125-128.

Tamura, K., Dudley, J., Nei, M. \& Kumar, S. (2007). MEGA4: molecular evolutionary genetics analysis (MEGA) software version 4.0. Mol Biol Evol 24, 1596-1599. 